\title{
MODERN WAR AND ITS ASYMMETRIC NATURE
}

\author{
Neno Hristov Hristov \\ Associate Professor, Ph.D., Dr.Sc., Military Academy, Sofia, Bulgaria
}

\begin{abstract}
In the context of the new security environment and related processes and ongoing world events, the scale of change and transformation in the logic of the military becomes more unintelligible. The most controversial one was always present and remains a question about the cause of wars.
\end{abstract}

Keywords: security environment, transformation, asymmetric wars, policy, culture, technology, economics, security, history warfare experience

\section{MAIN TEXT}

All the time people tried to comprehend the phenomenon of war, to reveal its nature, give it moral judgments, to develop methods for its most efficient use (the theory of military art) and to find ways of limiting or even eliminating it. The most controversial one was always present and remains a question about the cause of wars: Why do they happen, if most people do not want them?

It is known that a process of accumulation of knowledge precedes the occurrence of any system of views; humanity goes from experience to theory. It is also based on many years of military experience used for development of different theory of war.

Current war theories are based on many factors: policy, culture, technology, economics, security environment and history warfare experience. Human dimensions of an armed conflict continue to be the core, which is developing war theory. The technology is a minor factor. The behavior and cruelty that we see in last wars show that after many centuries history, human nature remains essentially unchanged. The core of the current and the past war theories are based on human values and human behavior.

Conflicts of the 20th century radically changed the world. The developed world order after World War II, stored for four decades of the Cold War, also known as bipolar world, collapsed in the early 90 's. So at the end of the 20th century a multipolar world grew up with a global superpower - the United States, with some great and regional powers, with a wide range of risks and threats, with new horizons of global and regional cooperation and integration, with the wider opportunities and challenges (globalization).

A conclusion was widely spread that the originator of the threats to international security is rooted in the growing gap between developed countries and the rest of the underdeveloped world, and the collapse of fundamental values. As key risks and security threats, have become international terrorism and crime and the proliferation of weapons of WMD. As in the last decade of the 20th century and early 21 st century, 
conflicts will arise more frequently as the intrastate and will be resolved exclusively by unions or coalitions. Consensus and compromise will be difficult to achieve.

The beginning of $21^{\text {st }}$ century confirmed the validity of the famous Clausewitz maxim "war is merely an extension of politics by other means". Recent conflicts in Bosnia, Kosovo, Afghanistan and Iraq have shown that the use of military force as an instrument for achieving the policy objective remains relevant today as it was in the past but with much wider scope.

In the context of the new security environment and related processes and ongoing world events, the scale of change and transformation in the logic of the military become more unintelligible. This made me think that the future war will be very different from the presently led. The existing war theories are not fully applicable to the new security environment. The past wars are good experience for us but the new security environment changes the situation in a way that there will not be more wars similar to this in the past. My personal theory is that the future belongs to the "asymmetric wars". The war will not be the only job for politicians, military and diplomats. This issue more and more should be an issue for different civilian branches. In my essay, I will try to give a different perspective about reasons that cratered current wars.

Considering the review of the literature of recent years the international relations show that the "asymmetric" relationship emerges as an increasingly important element of analysis: „asymmetric threats”, "asymmetric warfare”, „asymmetric war". Most often, the term „asymmetry” is used to characterize the relationship between incomparable in power and status opponents. The most popular mythological analogy in this context is about the battle between David and Goliath. With the exception of some relatively small number, military-strategic and normative-legal analysis, highlighting the asymmetry, as a rule is related to the paradoxical nature of relations in which the weaker opponent is able to cause detriment and even impose its „will” over the more powerful side, while powerful cannot always be at their interests and to subjugate the weak.

An analysis of strategy and tactics of struggle of the weak against the strong is the nature of the problem of "asymmetric relations". Moreover, if theorists and analysts are more interested to find the answer of the question „why it is possible victory of the weak or what makes the defeat of the more powerful side?” For practitioners (politicians and military) it is more important to find the optimal strategy in behaviors for such cases.

In the year 2000, the Secretary of Defense William Cohen noted the existence of the so-called. „Superpower paradox" - that situation in which no country in the world can directly challenge the United States, but can threaten them indirectly, through „asymmetric wars”, in the form of „chemical, bacteriological or even nuclear war". In this context, the term „asymmetric war” (asymmetric warfare) means a blackmail situation where the weaker player threatens to use weapons of mass destruction against civilians of the enemy. Characteristic of such situations is the double blackmail - i.e. obviously unacceptable threat to the stronger side developments, such as weak player deliberately violates the rules of the game, using prohibited means of pressure against the man who created and seeks to impose these rules.

After the terrorist attacks of 2001, the term "asymmetric threats" is used in relation to terrorism and the danger that international terrorist groups can acquire weapons of mass destruction. Director of the Center for the Study of Terrorism and political violence (to the British University „St. Andrews”) Paul Wilkinson defines this situation as a "realization of the straight of the weak against the weakness of the strong”, metaphorically compares the fight against terrorism with this of football goalkeeper: he can "hundreds of times to protect the door of his team, but people will still remember the only goal that has made".

Beginning of military operation in Iraq (in 2003) and the inability of the coalition, led by the most powerful country in the world, to end the war in accordance with their original plans (i.e. to establish full control over the country after the defeat of its army) and transformation of military operations in to guerrilla warfare, is determined by experts as a classic example of „asymmetric war”, which can be compared to Vietnam. In the Iraqi war, there is a clear disproportion between the power capabilities of adversaries, their status and their military tactics. Moreover, in the early $60^{\prime s}$ of the last century, partisan wars in terms of occupation or colonial rule and national liberation movements, were assigned to asymmetric wars. Today's realities, however, make us re-analyze them as a specific model of armed confrontation.

If deducing the matching elements of those cases, we can identify some basic features of asymmetric wars:

- Unpredictability of the result of them, obviously not equal power capabilities and status of the opposing sides;

- The use of strategy by the weak built on search of "the weakness of the strong"; 
- The use of the weaker party prohibited of means of conducting military operations;

- The tactics of "indirect" military action used by the weaker party;

- The inability of the strong party to withstand its position definitely crushes the weak.

Consequently, specifying the definition above, we can say that the asymmetry is typical of those paradoxical situations of war in which powerful opponent is unable to protect and achieve victory over the weak (1994). In most such conflicts, weak opponent is unable to achieve victory over the strong. As a rule, however, he first manages to impose over the strong beneficial way himself for development of the conflict. In this sense, the weak imposes his "will" to the strong and manages to achieve political victory, because that is actually used by, according to the classical definition of war.

From the $60^{\text {ist }}$ until present years, the concept of asymmetry is used by specialists in international relations, political scientists and military experts to analyze the conflicts between developed and developing countries. The study of paradoxes of asymmetric wars and attempts to formulate a theoretical justification are dedicated in the works of Andrew Mack, Ivan Erigin-Taft, Michael Fisherkelar and Zeev Maoz, Meram. They repeated the argument that the success of the military campaign in such a conflict does not depend so much from the potential adversary's power, as to the interaction between the military-strategic and tactical factors with non-military factors for victory, i.e. political, psychological and ideological parameters of the situation. As observed by many researchers to achieve victory is necessary support for the war by the whole society of a belligerent state, i.e. their legitimacy. In addition, this factor is crucial for both the strong and the weak country.

In his book "Why big nations lose small wars?" (1975) Andrew Mack notes that behind the disparities between the power capabilities of the participants in the conflict may be hidden and more important asymmetries - such as asymmetry in the relationship to the specific war or asymmetry in the ability of countries to mobilize the community in its support. The second type of asymmetries is manifested dichotomy in "limited" and "total» war or the use of asymmetric tactics - actions of guerrilla groups against the regular army. Often it is this type of asymmetries that explain the reasons for victory of the weak and defeat of the strong.

The main thesis of Andrew Mack is that usually the war loses those who has lost the political "will" to continue it. The most important condition for the existence of such a "will" is public support of the war. According to Andrew Mack, democratic countries often lose "small wars" of the "internal front" because they are unable to mobilize the community to continue the war and to provide requisite justification of its objectives, human casualties and material losses and loses its war legitimacy in the eyes of the nation. Only those countries that actually wage war in the name of meaningful and universal concept, are capable long enough to maintain the mobilization of available human and material resources needed to achieve victory against a superior enemy force. In this strong attachment of the public to the goals,, war that will take us closer to the idea of "absolute war”, more so its logic, as a rule, prevails over the logic of „restricted” or „small” war.

In his fundamental work „War and peace between nations» Raymond Aron noted that the reason for the defeat of the Great Powers in the colonial wars of the twentieth century can be explained by the asymmetry of relations "rebel-Colonist". Despite, the inequality of forces, Aron stresses on the asymmetry of „willingness, interest and antipathies in belligerent dialogue between conservatives and rebels", which „is the final cause of what French authors define as defeat of the West" (2003a). The asymmetry of will and interest explains why during the $60^{\text {ies }}$ the formally stronger country (France) refuses to continue the fight against the weaker opponent (Algeria).

Besides those already mentioned limited nature of the hostilities, the phenomenon of "small war” also gives evidence of poor adherence to the purposes of war by a stronger nation. At some point, the benefits of achieving a military victory began to be perceived by society as insufficient to justify the substantial human, material and moral losses from continuing the war. For the governments of democratic countries is becoming increasingly difficult to justify the purpose of war (especially the „small”) that leads and provides the necessary public support for the initiation and their continuation.

This hypothesis brings us back to the least contested thesis of Immanuel Kant for lasting peace among the nations under which enlightened societies do not support aggressive foreign policies of their governments. Significant in this respect is the title of the book by G Merom „How democracies lose small wars”, analyzing asymmetric conflicts. The author deliberately puts into question the view affirmed for the peaceful nature of democracies in the light of criticism of the theory of "democratic peace", and thus further substantiate launched by other analysts view the causes of damage of the developed countries in conflicts in the Third 
world. G Merom notes that political scientists often consider society as a passive object involved in military actions by political and military elite, without considering the complex nature of the relationship between society, state and war (2003b). Disputing with supporters of „political realism”, the author demonstrates that contemporary "power paradox" is explained by the internal struggle in democratic states between the "state" and educated "middle class". It is the latter that forms the basis of "community" and set its behavior to the three aspects of conducting a war: instrumental, political and normative. G Merom formulates these relations by the following three dilemmas:

- How to reconcile the values of humanism, which adheres to the part of the educated middle class, with atrocities accompanying anti-insurgency wars;

- How to find an acceptable balance for the public between the atrocities of war and willingness to make sacrifices in its behalf;

- How to provide adequate support for the war without eroding the foundations of democratic order.

The last dilemma - the 'ratio' between war and democracy - directly illustrates the above-mentioned trend of distortion or restriction of democratic principles and values in the societies, leading a war (1964).

Over the past 60 years after the Second World War, many national liberation and anti-colonial movements used strategy of guerrilla warfare with which they were able to exhaust if not the power of the enemy but it's „will", forcing him to agree to concessions. The known theories of Mao Zedong for strategy and tactics of guerrilla warfare (15), are remarkably consistent with the reasons for U.S. defeat in Vietnam War (19641975), appointed by Henry Kissinger. Both see the reasons for the victory of the Vietnamese during the long war, which exhausts the U.S., despite their military superiority. North Vietnam success is due to the guerrilla tactics of "small wins", enabled the Communist forces to avoid direct confrontations with U.S. forces. Hardly detectable invulnerable and scattered forces of the Vietnamese guerrillas against easily found concentration of U.S. troops. Moreover, the local population supports the communist resistance, seeing the fight against U.S. forces as „fair and liberation“.

So for the weaker party in the Vietnam War was sufficient "not to lose“. On the other hand, to win the strong country needs a mandatory peremptory military victory. Kissinger even derives "formula for the victory of Guerrilla”: „Partisans win until not losing, the regular armies defeated until they fail to win a decisive victory”. Again, he indicates another important factor for victory - the ability of each party to provide security for civilians in the area of hostilities. Wins the force (whether regular army or guerrillas) that can achieve this to the maximum. Such a task, however, it is often impossible for the regular army, which is fighting abroad. In this sense local guerrillas' sooner or later are doomed to win".

Terrorism at the beginning of the XXI century is a version of asymmetric warfare as embodied logic of the struggle of "weak" against the "strong”. Herfrid Munkler a German scholar argues that terrorism (as a means to combat the "weak") "replaced the guerrilla war which in a long period of the twentieth century was performing that function." This treat is not described by the famous theorists of wars and led me to develop my new vision about the war. Terrorism differs from guerrilla warfare with its offensive nature, the weaker dependence on the local population and the ability actively to use the infrastructure of developed countries for their own purposes. Modern terrorism is a form of war in its classical interpretation by forcibly imposing one's will on the opponent with this important feature, that terrorism combat is "oriented to asymmetry whereby players who are infinitely worse in the technology and organization planning from their opponent, proved able to fight successfully in the past".

The difference between guerrilla warfare and terrorist strategies is in the deliberate use of the paradoxical advantages of strategic asymmetry. Traditional guerrilla movements are seeking to achieve symmetry in its relations with the enemy and then to achieve victory in armed struggle with it. In turn, terrorist groups seek to erode the moral and psychological potential of the enemy without coming into direct contact with its military machine. In doing so, they choose to hit the most vulnerable targets of in one or another country, thus avoiding all military barriers and safeguards, for which modern societies invest so much money trying to ensure their safety.

Considering the above said, as an important methodological problem in forecasting the prospects of armed conflict has emerged not only comparative analysis of the potential of opposing sides, but the possibility of symmetric or asymmetric use of some other elements of these potentials. In such an analysis a relatively persistent („structural”) and variable („dynamic”) characteristics of the conflict it is important. The first includes power and resource opportunities, also the legal status of the parties, their goals, the state of their societies, and their attitude to this conflict. The second includes the later accepted strategies and tactics by either party used to offset the obvious disparities in their power. 
In the second half of the twentieth century, there was a certain desire in the international politics, to comply with the specifics of asymmetric wars. Thus, countries tried to modify the strategy of their military actions, taking into account the specifics of the fight against relatively weak opponents. In this light, the following trends emerged:

- Developing of scenarios for direct military clashes with small-scale (the strategies of „local wars”, „limited war" and „low intensity conflicts");

- Preparation of the armed forces to conduct combat operations with a relatively small number of troops by specially trained troops;

- Implementation of preventive actions against irregular enemy forces and optimal use of intelligence agents and networks;

- Implement measures to ensure constant contact with the local population, whose protector is made the weaker opponent, and providing military and material support of their own supporters in the local community;

- Limiting the scale of military operations and using non-military methods, ways to pressure the weaker opponents.

General trend was the shift to more carefully measured use of military force and desire to avoid direct military intervention in internal conflicts in foreign countries, and greater use of non-military forms of pressure. The negotiation process approaches also changed. First, the treatment of the status of participants in the negotiations became more flexible, i.e. an arrangement was reached easier to conduct negotiations based on informal equality between the participants. Secondly, more attention began to be paid to respect the interests of the weaker side and demand "balance of interests' between participants in the conflict. These changes, showed the unsuccessful attempt from the previous negotiating tactics of the "superior position of the party", were the result of using methods of mathematical modeling of conflict.

Among the factors influencing the outcome of asymmetric conflicts, was the strengthening of the normative and value approaches in international politics in the postwar period. Long time concepts such as justice and legitimacy were associated with the legal system inherent to the closed socium, but that during that period they have become the foundations of international politics. Post-war structure was based on democratic values and principles, whose gradual realization was creating conflict between the norms, principles and officially declared values on the one hand, and the actual conditions in which the international system worked, uniting very diverse „players” from- the other using. Experts in the field of international relations have begun to devote increasing attention to non-military reasons for dominance in the world of developed countries. Thus, launching theory of „hegemonic stability”, Robert Gilpin concludes that the domination of the hegemony is accepted because it guarantees certain benefits to other participants in the system - such as security and favorable economic conditions and can be supported by ideological, religious or other values that are common to a group of countries.

The emergence of transnational terrorism threat, directed against developed countries, broke illusions of increasing "control ability of" the international system and the possibilities to reach compromise between asymmetric antagonists. Contemporary manifestations of terrorism leaves open the fundamental question: "what political objectives are these groups pursuing and how consistent are the political objectives with terrorist objectives and are the values of countries against which they struggle". In this regard, the American specialist in counter-terrorism, Jonathan Stevenson, stated that two options are response of the possible by the "strong" one: one is the surrender, negotiations with terrorists and abandon the protection of allies and the other - full-scale mobilization of the West (which, in itself, is a risky and destructive).

In the fight against transnational terrorism, the various governments strengthen internal control, strive to do impermeable the state borders, and persuade citizens in need of nationwide mobilization against this threat that is even globalized. Many experts evaluate their actions as a deliberate restriction of democratic freedoms in the name of security. The asymmetry of this fight required new asymmetric political thinking.

The study of asymmetry in international politics brings us back to dispute about relationship between power, norms and values in the international system. This new relation raised in the last 20 years in connection with new word security environment affected the phenomenon „WAR”, changing its nature from predictable to not predictable results. All this will force the developed countries to reconsider their theories about what creates wars and how they should be conducting it. The asymmetric damnations of new war required asymmetric decisions and actions. This made me think that we have to change the current theories of war. 


\section{REFERENCE LIST}

http://www.securitymanagement.com/library/000339.html 1.

T.M. Paul. (1994). Asymmetric conflicts: War initiation by Weaker Power. New York: Cambridge University Press.

A. Mack. (1975). „Why Big Nations Lose Small Wars: The Politics of Asymmetric Conflict", World PoliticsVol. 27, No.2 (1975).

Raymond Aron Peace and War: A theory of international relations. New Brunswick New Jersey (2003a)

G. Merom, (2003b). How Democracies Lose Small Wars, New York: Cambridge University Press, p 3 Ibid. P. 229-231 6.

Q. Wright. A Study of War. Chicago: Phoenix Books, (1964). P.161. 